*ak FMIS View/Frint Document Cover Sheet tow

This document was retrieved from the Documentation and Records Manaqement (DRM) ISEARCH System. It is intended for Information only and may not be the most recent or updated version. Contact a Document Service Center (see Hanford Info for locations) if you need additional retrieval information.

Accession \#: D196033540

Document \#: SD-WM-TP-430

Title/Desc:

SAMPLE PREPARATION OF TANK 241C106 GRAB SAMPLES \& TESTING FOR COMPATIBILITY WITH TANK 241AY102 SUPERNATE

Pages: 22 
sta.4 (

\section{FEB 231996 ENGINEERING DATA TRANSMITTAL}

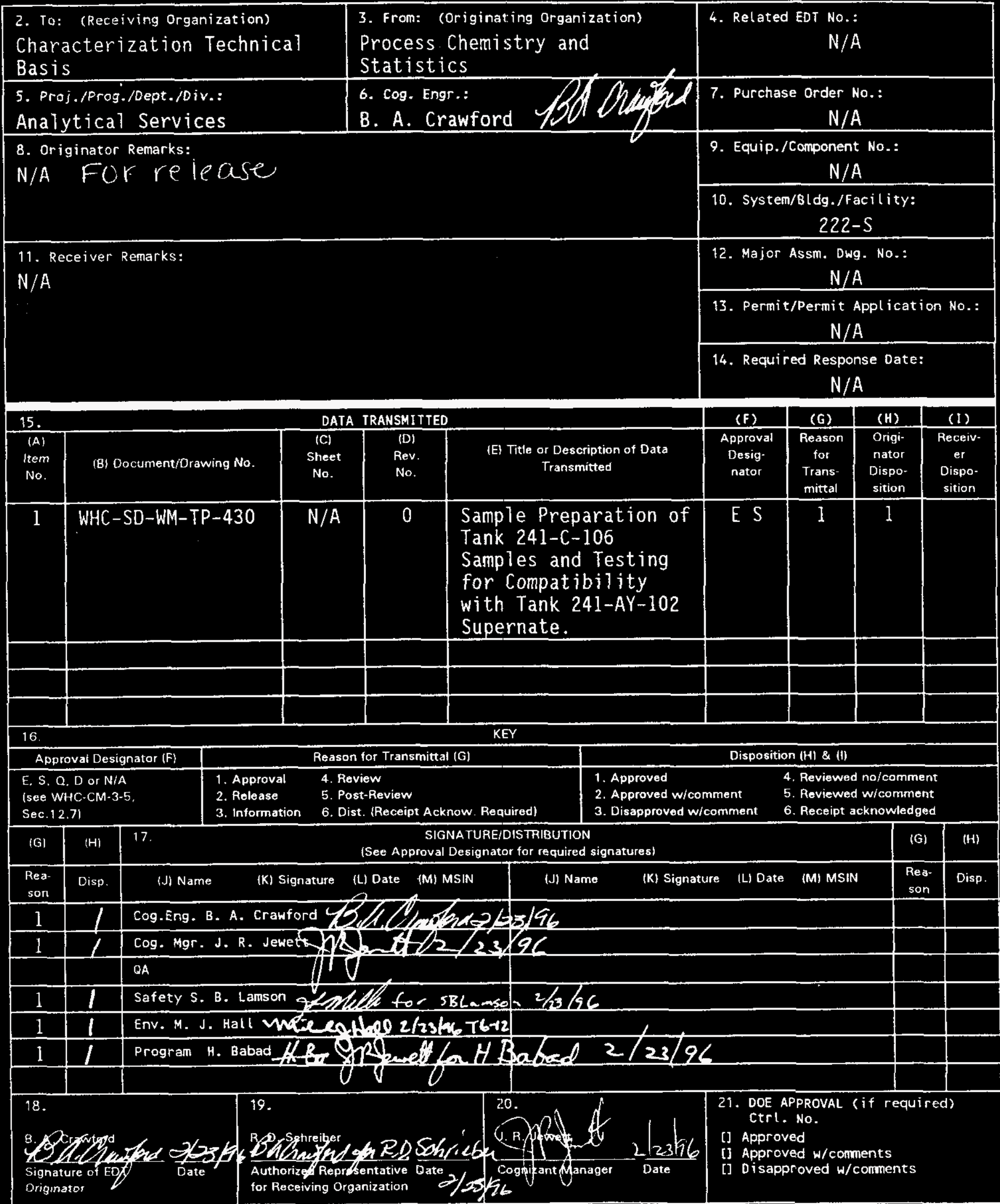




\title{
SAMPLE PREPARATION OF TANK 241-C-106 GRAB SAMPLES AND TESTING FOR COMPATIBILITY WITH TANK 241-AY-102 SUPERNATE
}

\section{B. A. Crawford}

Westinghouse, Richland, WA 99352

U.S. Department of Energy Contract DE-AC06-87RL 10930

\author{
EDT/ECN: $601908 \quad$ UC: 2070 \\ Org Code: 75764 Charge Code: MD389 \\ B\&R Code: EW31z0074 Total Pages: tet fortit \\ ol cl/32 $3 / 23 / 46$
}

Key Words: Sample Preparation, Tank 241-C-106

Abstract: This test plan describes a sample separation method which will be used to obtain physical measurements and separated 241-C-106 solids and supernate fractions. In addition compatibility of tank 241-C-106 sludge with tank 24l-AY-102 supernate will be determined.

TRADEMARK DISCLAIMER. Reference herein to any specific commercial product, process, or service by trade name, trademark, manufacturer, or otherwise, does not necessarily constitute or imply its its contractors or subcontractors.

Printed in the United States of America. To obtain copies of this document, contact: WHC/BCS Document Control Services, P.0. Box 1970, Mailstop H6-08, Richland WA 99352, Phone (509) 372-2420;
Fax (509) 376-4989.
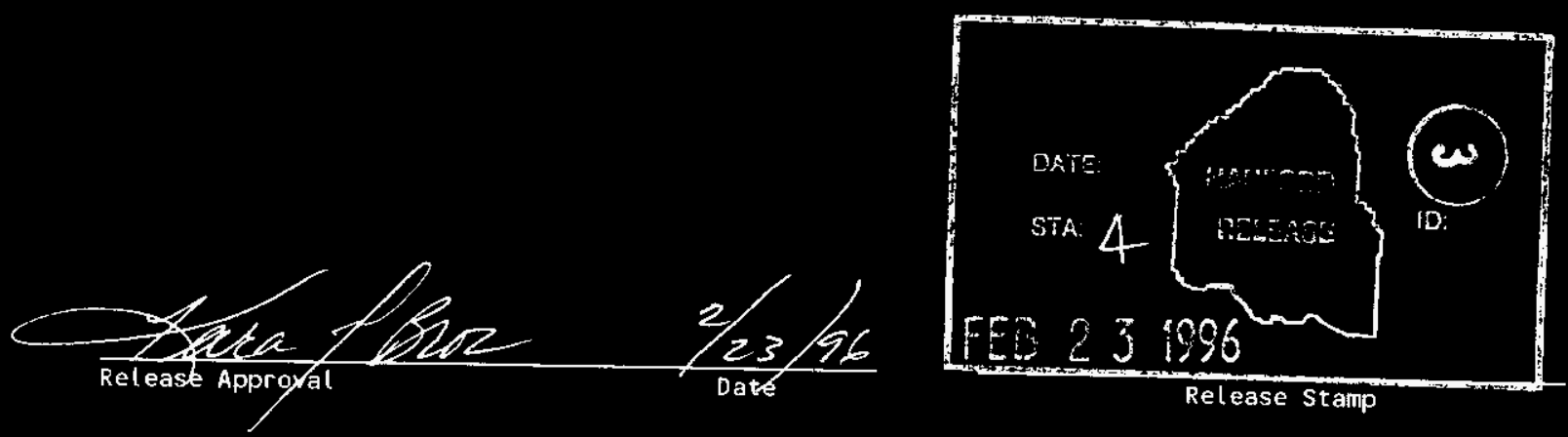
WHC-SD-WM-TP-430 Rev. 0

SAMPLE PREPARATION OF TANK 241-C-106 SAMPLES AND TESTING FOR COMPATIBILITY WITH TANK 241-AY-102 SUPERNATE

\section{TABLE OF CONTENTS}

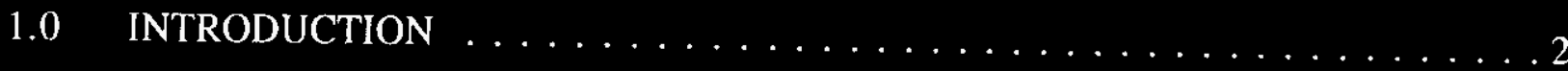

2.0 OBJECTIVE $\ldots \ldots \ldots \ldots \ldots \ldots \ldots \ldots \ldots \ldots \ldots \ldots \ldots \ldots \ldots \ldots \ldots \ldots \ldots \ldots$

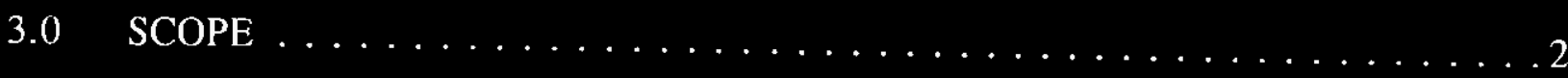

4.0 SAMPLE DESCRIPTION $\ldots \ldots \ldots \ldots \ldots \ldots \ldots \ldots \ldots \ldots \ldots \ldots$

5.0 SAMPLE HANDLING AND SUBSAMPLING $\ldots \ldots \ldots \ldots$

5.1 Sample Handling Diagram $\ldots \ldots \ldots \ldots \ldots \ldots$

5.2 Sample Handling Procedure $\ldots \ldots \ldots \ldots \ldots$

6.0 COMPATIBILITY TEST PROCEDURE $\ldots \ldots \ldots \ldots \ldots \ldots \ldots \ldots \ldots$

6.1 Tank 241-C-106 Sludge mixed with neat 241-AY-102 Supernate . . . . . 12

6.2 Tank 241-C-106 Sludge mixed with dilute 241-AY-102 Supernate . . . . 13

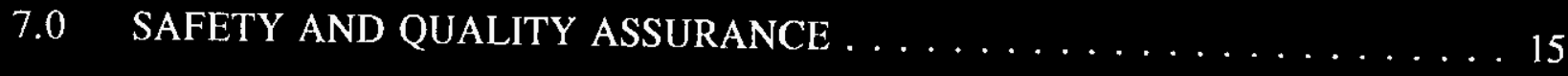

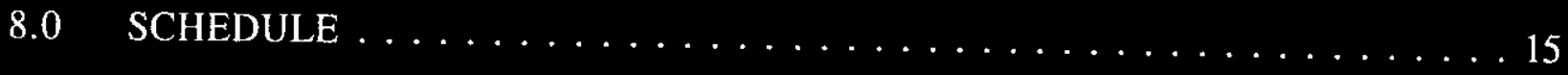

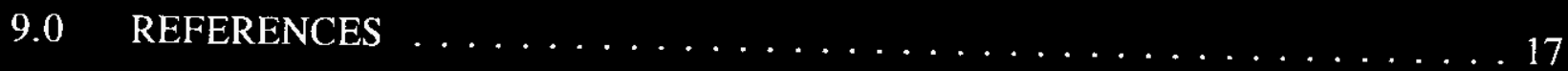


WHC-SD-WM-TP-430 Rev. 0

\section{SAMPLE PREPARATION OF TANK 241-C-106 SAMPLES AND TESTING FOR COMPATIBILITY WITH TANK 241-AY-102 SUPERNATE}

\subsection{INTRODUCTION}

Tank 241-C-106 is a high-heat organic-containing single-shell tank. The contents of the tank are to be sluiced to tank 241-AY-101 using tank 241-AY-102 supernate (Sederburg 1994). Therefore, tank wastes must be characterized to prevent chemical incompatibilities and possible creation of an unreviewed safety question (USQ). Sampling and analysis will provide updated information to support assumptions and conclusions in the tank 241-C-106 safety analysis for waste retrieval. In the safety assessment the organic content, tank heat loading, radiocesium, strontium and transuranic (TRU) content are of concern (Babad 1996). In addition, the tank is known to contain solids which may be difficult to separate from the supernatant solution. Therefore, to obtain the most accurate solids and liquids analyses, a non-routine separation method will be used by the Process Chemistry and Statistics (PCS) group to effect the cleanest separation. The procedure described in this plan will be used to perform these separations. In addition, PCS will perform physical measurements $\left(\% \mathrm{H}_{2} \mathrm{O}\right.$ in sludge, dry particle density, bulk density, viscosity particle size, and \% settled solids) and compatibility tests which are important to retrieval and sluicing of the tank contents (Fowler 1995).

\subsection{OBJECTIVE}

This plan provides the sample preparation method which will be used to obtain physical measurements and separated 241-C-106 solids and supernate fractions for analysis by Analytical Services. The plan is designed to:

- maintain tank temperature throughout processing;

- separate the sample solids and liquids by the most effective remote method possible;

- provide radiologically safe sample handling;

- determine waste compatibility and physical constraints for sluicing 241-C-106 waste solids with tank 241-AY-102 supernate.

\subsection{SCOPE}

This plan satisfies the sample preparation requirements of the sampling and analysis plan prepared for tank 241-C-106 grab samples (Schreiber 1996). 


\section{WHC-SD-WM-TP-430 Rev. 0}

In particular, this test plan describes specific procedures that will be used to separate and subsample tank 241-C-106 grab samples and determine physical properties needed for sluicing with tank 241-AY-102 supernate. The separation will provide clean supernatant solution and well-drained solid fractions. The separated fractions will then be submitted for analysis according to the project sampling and analysis plan (Schreiber 1996). In addition, tank 241-C-106 sludge will be mixed with both neat tank 241-AY-102 supernate and tank 241-AY-102 supernate diluted with tempered water (see attachment 1). Because of the high radiological content of the tank material, the sample preparation will be performed in PCS hot cells.

\subsection{SAMPLE DESCRIPTION}

Samples of both the supernatant liquid and the sludge from tank 241-C-106 will be received.

Tank 241-C-106 is known to contain wastes from several processes which were in operation at Hanford from 1947 to 1978 . The types of wastes which have been fed to the tank include: metal waste from the bismuth phosphate process, tributyl phosphate (TBP) wastes from the Uranium Recovery (UR) process, PUREX high-level acid waste supernate, aluminum cladding waste, PUREX sludge wash waste, B-plant low-level waste and strontium sludge waste . A homogenized core of the resulting matrix has been characterized (Weiss 1988). The $\mathrm{Sr}-90$ present is believed to create the high heat conditions observed in the tank [tank temperatures are reported at $55^{\circ} \mathrm{C}$ (Sederburg 1994)]. Since the tank is heat-generating, management of tank material includes addition of water to the tank for cooling. Therefore, analytical results provide a range of values based on concentration and dilution of materials with the water additions. The ranges reported for solids and liquids from tank 241-C-106 are provided in Tables 1 and 2 (Castaing, 1993):

\begin{tabular}{|c|c|c|c|}
\hline \multirow{2}{*}{ Component } & \multicolumn{2}{|c|}{ Range } & \multirow{2}{*}{ Average } \\
\hline & I ow & Hig & \\
\hline \% Solids & - & - & 55 vol. $\%$ \\
\hline$\%$ Water & - & - & 45 wt. $\%$ \\
\hline Bulk Density & $1.37 \mathrm{~g} / \mathrm{mL}$ & $1.43 \mathrm{~g} / \mathrm{mL}$ & $1.40 \mathrm{~g} / \mathrm{mL}$ \\
\hline $\mathrm{F}^{-}$ & 86 & 720 & 403 \\
\hline $\mathrm{NO}_{3}^{-}$ & 928 & 1330 & 1129 \\
\hline $\mathrm{PO}_{4}{ }^{3-}$ & - & - & 93,700 \\
\hline
\end{tabular}


WHC-SD-WM-TP-430 Rev. 0

\begin{tabular}{|c|c|c|c|}
\hline \multicolumn{4}{|c|}{$\begin{array}{c}\text { Table } 1 \text { - Tank 241-C-106 Solids } \\
\text { (mg/kg unless noted) }\end{array}$} \\
\hline \multirow[t]{2}{*}{ Component } & \multicolumn{2}{|c|}{ Range } & \multirow[t]{2}{*}{ Average } \\
\hline & Low & High & \\
\hline $\mathrm{SO}_{4}{ }^{2-}$ & 936 & 4850 & 2893 \\
\hline $\mathrm{Al}$ & 30,000 & 40,900 & 35,450 \\
\hline $\mathrm{Ba}$ & - & - & 4890 \\
\hline $\mathrm{Ca}$ & - & - & 11,900 \\
\hline $\mathrm{Cr}$ & 984 & 1350 & 1167 \\
\hline $\mathrm{Fe}$ & 52,100 & 64,100 & 58,100 \\
\hline $\mathrm{La}$ & - & - & 5960 \\
\hline $\mathrm{Pb}$ & - & - & 1060 \\
\hline $\mathrm{Mg}$ & 461 & 6560 & 3511 \\
\hline $\mathrm{Mn}$ & 1840 & 14100 & 7970 \\
\hline $\mathrm{P}$ & - & - & 9210 \\
\hline K & - & - & 1470 \\
\hline $\mathrm{Si}$ & 20,600 & 71,000 & 45,800 \\
\hline $\mathrm{Na}$ & 35800 & 117000 & 76,400 \\
\hline U & .00088 & 406 & 203 \\
\hline $\mathrm{Zr}$ & 735 & 2170 & 1453 \\
\hline $\begin{array}{l}\text { TOC (total } \\
\text { organic carbon) }\end{array}$ & - & - & 4620 \\
\hline $\begin{array}{l}\text { TRU } \\
\text { (transuranic) }\end{array}$ & - & - & $3050 \mu \mathrm{Ci} / \mathrm{kg}$ \\
\hline Total gamma & - & - & $363,000 \mu \mathrm{Ci} / \mathrm{kg}$ \\
\hline $\mathrm{Pu}-239 / 240$ & $1530 \mu \mathrm{Ci} / \mathrm{kg}$ & $5520 \mu \mathrm{Ci} / \mathrm{kg}$ & $3367 \mu \mathrm{Ci} / \mathrm{kg}$ \\
\hline Rare Earths & - & - & $450,000 \mu \mathrm{Ci} / \mathrm{kg}$ \\
\hline
\end{tabular}


WHC-SD-WM-TP-430 Rev. 0

Table 1 - Tank 241-C-106 Solids

(mg/kg unless noted)

\begin{tabular}{||l|l|l|c|}
\hline \multirow{2}{*}{ Component } & \multicolumn{2}{|c|}{ Range } & \multirow{2}{*}{ Average } \\
\cline { 2 - 4 } & \multicolumn{1}{|c|}{ Low } & High & \\
\hline $\mathrm{Cs}-137$ & $213,000 \mu \mathrm{Ci} / \mathrm{kg}$ & $330,000 \mu \mathrm{Ci} / \mathrm{kg}$ & $271,500 \mu \mathrm{Ci} / \mathrm{kg}$ \\
\hline $\mathrm{Sr}-89 / 90$ & $6 \mu \mathrm{Ci} / \mathrm{kg}$ & $1,980,000 \mu \mathrm{Ci} / \mathrm{kg}$ & $990,003 \mu \mathrm{Ci} / \mathrm{kg}$ \\
\hline
\end{tabular}

Table 2 - Tank 241-C-106 Liquids (mg/L unless noted)

\begin{tabular}{|c|c|c|c|}
\hline \multirow[t]{2}{*}{ Component } & \multicolumn{2}{|l|}{ Range } & \multirow[t]{2}{*}{ Average } \\
\hline & Low & High & \\
\hline$\%$ Solids & - & - & 22.57 vol. $\%$ \\
\hline$\%$ Water & - & - & 77.43 wt. \% \\
\hline SpG & $1.14 \mathrm{~g} / \mathrm{mL}$ & $1.18 \mathrm{~g} / \mathrm{mL}$ & $1.16 \mathrm{~g} / \mathrm{mL}$ \\
\hline $\mathrm{Cl}^{-}$ & 147 & 802 & 554 \\
\hline $\mathrm{CO}_{3}^{2-}$ & 18,600 & 91,900 & 44,860 \\
\hline$F^{-}$ & 15 & 530 & 164 \\
\hline $\mathrm{NO}_{2}^{-}$ & 2985 & 13248 & 9750 \\
\hline $\mathrm{NO}_{3}^{-}$ & 1400 & 112,220 & 67,156 \\
\hline $\mathrm{OH}^{-}$ & $.029 \mathrm{M}$ & $.324 \mathrm{M}$ & $.176 \mathrm{M}$ \\
\hline $\mathrm{PO}_{4}{ }^{3-}$ & 846 & 11,100 & 4039 \\
\hline $\mathrm{SO}_{4}^{2 \cdot}$ & 3520 & 6470 & 4995 \\
\hline $\mathrm{Al}$ & 34 & 752.6 & 270.1 \\
\hline $\mathrm{Bi}$ & 111 & 2000 & 1056 \\
\hline $\mathrm{Si}$ & 105 & 2580 & 1343 \\
\hline $\mathrm{Na}$ & 73,830 & 127,420 & 91,094 \\
\hline U & 162 & 958 & 560 \\
\hline
\end{tabular}


WHC-SD-WM-TP-430 Rev. 0

\begin{tabular}{|l|l|l|l||}
\hline \multicolumn{4}{|c|}{ Table 2 - Tank 241-C-106 Liquids } \\
(mg/L unless noted)
\end{tabular}

Samples are expected to be received at the laboratory in $125 \mathrm{~mL}$ dip bottles which must be loaded into the hot cell once sample delivery is made. The samples will be processed in the hot cell at approximately $60^{\circ} \mathrm{C}$ in a water bath to duplicate tank conditions. 
WHC-SD-WM-TP-430 Rev. 0

\subsection{SAMPLE HANDLING AND SUBSAMPLING}

\subsection{Sample Handling Diagram}

Tank supernate and sludge samples will be prepared and split according to the diagrams which follow:

\section{Supernate}

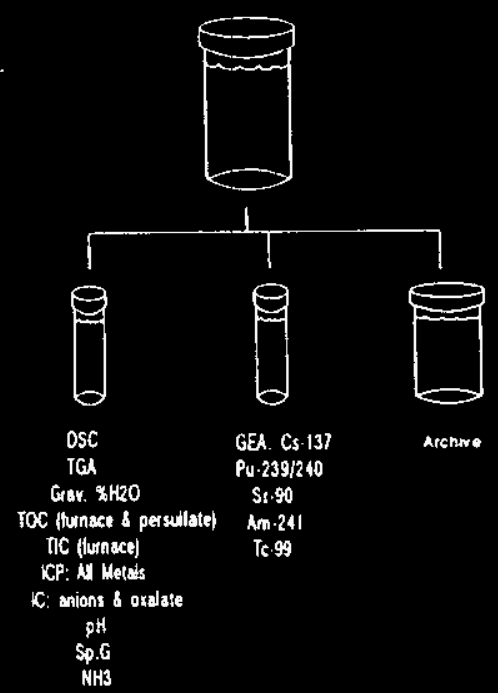

\section{Sludge (1)}

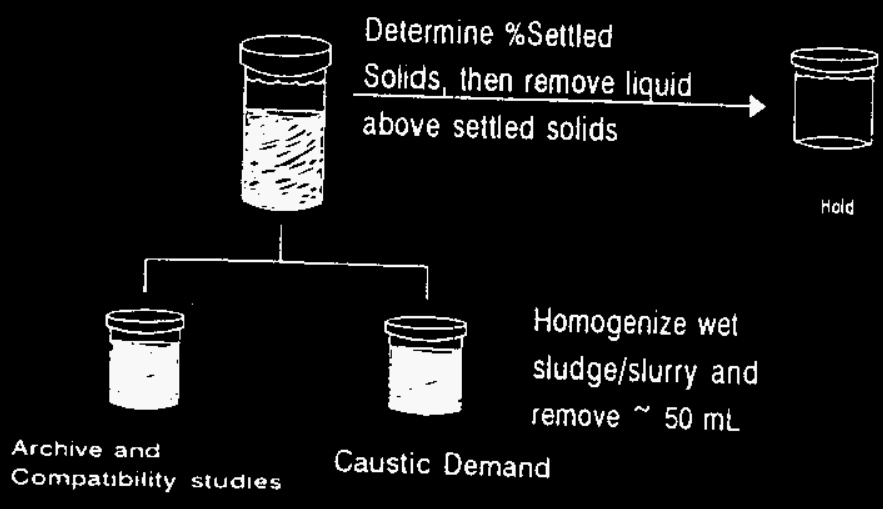


WHC-SD-WM-TP-430 Rev. 0

\section{Sludge (2)}

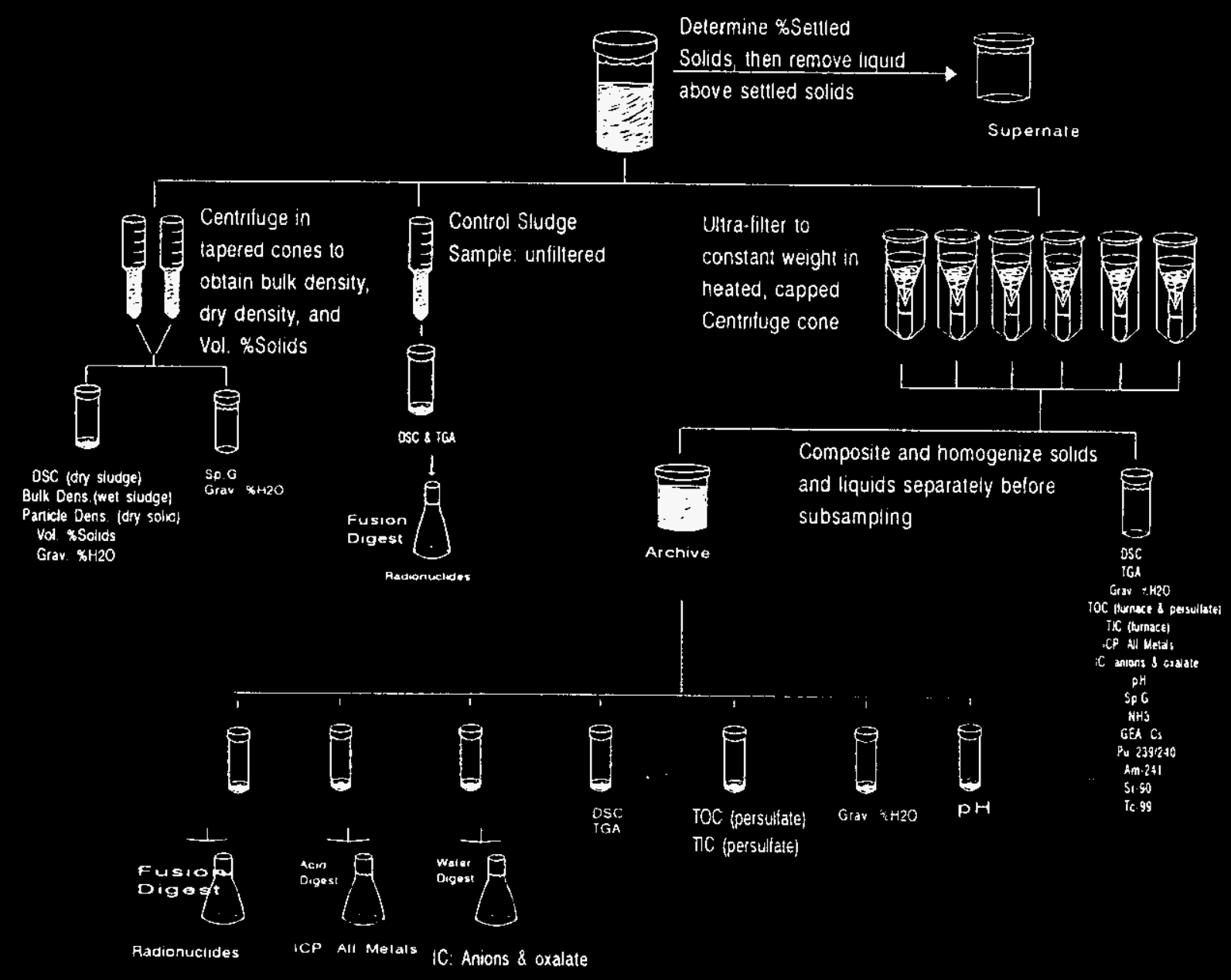




\section{WHC-SD-WM-TP-430 Rev. 0}

\subsection{Sample Handling Procedure}

\subsection{Sample Receipt}

Note - Record all observations in a controlled laboratory notebook.

1.1 Load-in samples to hot cell.

Note - $\quad$ Samples must be checked for an organic layer during observation.

1.2 Observe samples as they are loaded in and measure the height of settled solids and whole sample with a ruler.

1.3 Place sample bottles into an approximately $60^{\circ} \mathrm{C}$ (within $5^{\circ} \mathrm{C}$ ) water bath.

1.4 Allow samples to come to temperature at least two hours before processing.

2.0 Dispense Supernate Solutions

Note - The number of supernate samples which will be analyzed depends on whether water has been added to the tank between sampling campaigns.

2.1 Decant at least $120 \mathrm{~mL}$ of solution into as many tared $60 \mathrm{~mL}$ ultrafilter membrane centrifuge cones as required.

2.2 Centrifuge supernate solutions at $60 \pm 5{ }^{\circ} \mathrm{C}$ until all liquid is filtered.

2.3 Dispense 15 to $20 \mathrm{~mL}$ of solution into each of two $22 \mathrm{~mL}$ labeled vials.

2.4 Dispense remaining supernate to a $60 \mathrm{~mL}$ container to be archived.

2.5 Load supernate samples out of hot cell and notify project coordinator that samples are ready for analysis.

3.0 Centrifuge and Perform Physical Measurements on Sludge

Note - $\quad$ Perform the procedure below on one sludge sample from each depth from both riser 1 and riser 7 . 


\section{WHC-SD-WM-TP-430 Rev. 0}

3.1 Remove excess supernate from settled sludge into a $60 \mathrm{~mL}$ archive container.

3.2 Homogenize sludge material by thorough stirring or agitation depending on the consistency of the sludge.

3.3 Select sample with least amount of sludge from the two bottles received from each depth and transfer 30 to $40 \mathrm{~mL}$ of it to a vial for caustic demand (Herting 1995) and particle size analyses.

3.4 Collect remaining material from that bottle in a $60 \mathrm{~mL}$ vial for archiving and compatibility studies (see section 6.0).

3.5 Place approximately 8 to $10 \mathrm{~mL}$ of homogenized sludge from the remaining bottle from each riser depth into each of two tapered, tare-weighed centrifuge cones, and approximately $5 \mathrm{~mL}$ in a third tapered centrifuge cone for a control sample.

3.6 Record the total volume of bulk material in each of the cones and the gross weights of each cone.

3.7 Centrifuge cones for 4 hours at $60 \pm 5{ }^{\circ} \mathrm{C}$ at high speed.

3.8 After 4 hours, record the volume of solids in the cone.

3.9 Record volume of bulk material, then decant supernate into a $22 \mathrm{~mL}$ vial and label for $\mathrm{SpG}$ (specific gravity) and gravimetric \% water.

3.10 Record the gross weight and volume of centrifuged solids in the cone.

3.11 Dry centrifuged solids uncovered at $70{ }^{\circ} \mathrm{C}$ by spinning in heated centrifuge for 24 hours.

Note - Notify shift operations to monitor ongoing operations.

3.12 Record gross weight of solids in cone.

3.13 Dry solids in centrifuge for an additional 60 minutes.

3.14 Record gross weight of solids in cone and compare with last reading obtained. If the difference between values is $<0.1 \mathrm{~g}$ continue to step 3.15 , otherwise repeat steps 3.13 through 3.14 . 
WHC-SD-WM-TP-430 Rev. 0

3.15 At constant weight, submit solid for DSC analysis.

4.0 Ultrafiltration of Solids and Sample Splitting

4.1 Homogenize solids from original sample (step 3.1).

CAUTION - Tank 241-C-106 material may contain high concentrations of organic complexants. Therefore, be certain that all cones and sample vials are compatible with these materials.

4.2 Spoon equal portions of homogenized sludge into tared ${ }^{1}$ Amicon ${ }^{\circledR}$ CF-25 membrane cones placed in tared uniquely labeled $60 \mathrm{~mL}$ cones with inserts and caps.

4.3 Record gross weights of each cone.

4.4 Centrifuge cones for 2 hours.

4.5 Record the gross weight of solids and membrane cones.

4.6 Reassemble centrifuge cone and centrifuge for one hour.

4.7 Record gross weight of solids and membrane cone and compare with the previous value obtained.

4.8 If the difference in gross weights obtained is $<0.1 \mathrm{~g}$ continue to subsampling (step 4.9), otherwise repeat steps 4.6 through 4.8 .

4.9 Decant supernate liquid into a tared and labeled collection vial.

4.10 Obtain gross weight of liquid vial and submit for analysis.

4.11 Collect solids into a tared and labeled archive container and homogenize.

4.12 Subsample solids into seven small aliquots with at least the amount of solids listed as follows:

Fusion - Radionuclides: $1.5 \mathrm{~g}$

Acid Digestion - ICP metals: $2.0 \mathrm{~g}$

Water Digestion - IC anions and oxalate: $1.5 \mathrm{~g}$

DSC/TGA: $1.0 \mathrm{~g}$

${ }^{1}$ Amicon is a registered trademark of Amicon Division, W.R. Grace and Co., Danvers, Massachusetts. 
TOC and TIC: $1.5 \mathrm{~g}$ gravimetric $\% \mathrm{H}_{2} \mathrm{O}: 2.0 \mathrm{~g}$ pH: $2.0 \mathrm{~g}$

\subsection{Sample Load out}

5.1 Load out the small aliquots from step 4.12 into labelled containers under HPT guidance.

5.2 Obtain dose rates in hotcell airlock.

5.3 If samples are too high in activity to be loaded out directly to hoods, STOP and place samples back into hot cell as directed under RWP S-273 and contact HPT management and cognizant chemist, immediately.

\subsection{COMPATIBILITY TEST PROCEDURE}

Compatibility testing will proceed according to the requirements described by Babad (see attachment 1 ). This testing will primarily be directed towards addressing sluicing concerns such as transfer line plugging rather than tank material energetics typically performed in compatability determinations (Fowler 1995). Specifically, supernate from tank 241-AY-102 will be added to 241-C-106 sludge in two determinations. The first determination will involve mixing neat 241-AY-102 supernate with tank 241-C-106 sludge using the sludge washing procedure for mixing described by Lumetta (Lumetta 1996). The second determination will be performed using dilute supernate. In all cases, once mixing is complete, visual observations (i.e. off-gassing, precipitation, color change, etc.) will be made and settling rates will be measured. The $\mathrm{pH}$ and specific gravity of the supernate will be determined before and after mixing. The weight, volume and density of sludge before and after mixing will be determined. The resulting supernate will be archived for additional testing (in the event that energetic information is needed).

\subsection{Tank 241-C-106 Sludge mixed with neat 241-AY-102 Supernate}

1. Calculate and record the amount of tank 241-C-106 sludge required to provide $10 \mathrm{wt} . \%$ sludge on a dry weight basis to 40 to $50 \mathrm{~mL}$ of tank $241-\mathrm{AY}-102$ supernate .

2. Tare a $100 \mathrm{~mL}$ clear plastic beaker containing a teflon coated stir bar.

3. Weigh the required amount of sludge added to the mixing container. Record weight. 
WHC-SD-WM-TP-430 Rev. 0

4. Obtain the $\mathrm{pH}$ of the tank $241-\mathrm{AY}-102$ supernate and remove a $\sim 1.0$ gram aliquot for $\mathrm{SpG}$ analysis.

5. Add $\sim 9$ grams of $241-\mathrm{AY}-102$ supernate to each gram of sludge (dry weight basis) used.

6. Record the total volume and weight of combined sludge and supernate and any visual observations.

7. Heat the mixture to $35^{\circ} \mathrm{C}$ and record any observations.

8. Stir mixture for 30 minutes.

9. Obtain and record the $\mathrm{pH}$ of the stirred solution.

10. Stop stirring and allow solids to settle by gravity.

11. Using a ruler, measure the top height of the stirred slurry (time $=0$ measurement).

12. Record the time and settled solids height at time intervals close to time $=0$ and 1 hr., 4 hrs., 8 hrs. and 24 hrs. after initiation of settling or until solution is clear.

13. Estimate the volume of settled solids by weighing an equal volume of water in an identical beaker to that used in 12 .

14. Obtain an aliquot of the resulting supernate for $\mathrm{SpG}$ analysis.

15. Obtain and record the $\mathrm{pH}$ of the final supernate.

16. Remove supernate from resulting solids.

17. Record the weight and volume of solids remaining after mixing with supernate.

6.2 Tank 241-C-106 Sludge mixed with dilute 241-AY-102 Supernate

Note - $\quad$ Tempered water will be prepared as $0.01 \mathrm{M} \mathrm{NaOH}$ and $0.011 \mathrm{M}$ $\mathrm{NaNO}_{2}$ solution by the 222-S Standards laboratory.

1. Prepare dilute solution of tank 241-AY-102 supernate by diluting 1 part by volume supernate with 2 parts tempered water. 


\section{WHC-SD-WM-TP-430 Rev. 0}

2. Calculate and record the amount of sludge required to provide $10 \mathrm{wt} . \%$ sludge on a dry weight basis to 40 to $50 \mathrm{~mL}$ of supernate.

3. Tare a $100 \mathrm{~mL}$ clear beaker containing a teflon stir bar.

4. Weigh and record the amount of sludge added to the mixing container.

5. Obtain the $\mathrm{pH}$ of the dilute tank $241-\mathrm{AY}-102$ supernate and remove a $\sim 1.0$ gram aliquot for $\mathrm{SpG}$ analysis.

6. Add $\sim 9$ grams of diluted 241-AY-102 supernate to each gram of sludge (dry weight basis) used.

7. Record the total volume and weight of combined sludge and supernate and any visual observations.

8. Heat the mixture to $35^{\circ} \mathrm{C}$ and record any observations.

9. Stir mixture for 30 minutes.

10. Obtain and record the $\mathrm{pH}$ of the stirred solution.

11. Stop stirring and allow solids to settle by gravity.

12. Using a ruler record the top height of the stirred slurry (time $=0$ measurement).

13. Record the time and settled solids height at time intervals close to time $=0$ and $1 \mathrm{hr} ., 4 \mathrm{hrs}$., $8 \mathrm{hrs}$. and $24 \mathrm{hrs}$. after initiation of settling or until solution is clear.

14. Estimate the volume of settled solids by weighing an equal volume of water in an identical beaker to that used in 12 .

15. Obtain an aliquot of the resulting supernate for $\mathrm{SpG}$ analysis.

16. Obtain and record the $\mathrm{pH}$ of the final supernate.

17. Remove supernate from resulting solids.

18. Record the weight and volume of solids remaining after mixing with supernate. 
WHC-SD-WM-TP-430 Rev. 0

\subsection{SAFETY AND QUALITY ASSURANCE}

All observations will be recorded in a controlled laboratory notebook and reviewed by a knowledgable scientist.

No quality control checks are required. However, results from the compatibility testing portion of this plan may provide additional information required to address the waste compatibility of tank 241-C-106 waste when added to tank 241-AY-102 supernate in sluicing to tank 241-AY-101. Therefore, this test plan has been approved for treatability requirements based on the compatibility specification described in the data quality objectives for tank farm compatibility (Fowler 1995).

Workers safety has been maximized in this plan by having most work performed in a hot cell. Normal radiation protection practises (RWP S-012) should be sufficient to minimize exposure to personnel.

Sample processing according to this plan will be performed remotely using manipulators in the hot cell. No reagents other than water will be used for rinsing, heating and processing of the samples. Heating and centrifuging will be preformed in the hot cell. Samples will be loaded into the hot cell as they are received and subsampled before distribution to Analytical Services. Sample load in, load out and dose rate measurements will be performed according to current procedure (LO-100-108, rev. A-1). An HPT will be in attendance during sample load out as required by RWP S-012.

\subsection{SCHEDULE}

The schedule provided below begins with receipt of sample and makes the following assumptions:

1) The test plan has been approved by the time of sample receipt.

2) All samples are received on the same day

Any delay in sampling schedule or sample receipt will impact the schedule by adding additional days to those described below.

\section{Day 1:}

- Load in samples

- Obtain visual information from samples 


\section{WHC-SD-WM-TP-430 Rev. 0}

Day 2:

- Place in heated water bath (2 hours)

- Decant supernate liquids and load out

- Split sludge into cones

- Obtain bulk density and \% solids measurements from tapered cones

- Centrifuge ultrafiltration cones to constant weight

- Obtain \% solids on centrifuged solids

Day 3:

- Begin drying tapered cones

- Combine centrifuged solids from ultrafiltration cones and homogenize.

- Combine liquids from ultrafiltration cones and submit

- Subsample solids from cones

Day 4:

- Request tempered water solution from Standards laboratory

- Calculate \% water and dry particle density from the tapered cones

- Continue subsampling solids

Day 5:

- Obtain pH of supernate

- Weigh sludge for compatibility testing

- Determine sludge density

- Complete observations and initiate mixing

- Complete settling rate and observations of solids

Day 6:

- Weigh sludge for compatibility testing

- Prepare dilute supernate solution

- Obtain pH of supernate

- Determine sludge density

- Complete observations and initiate mixing

- Complete settling rate and observations of solids 
WHC-SD-WM-TP-430 Rev. 0

\subsection{REFERENCES}

1. Internal Memo, H. Babad, R. Cash to R. A. Esch, R. D. Schreiber, and J. P. Harris III, "Tank 241-C-106 Grab Sample - Technical Letter of Instruction," dated January 4, 1996.

2. Lumetta, G., "Sludge Washing and Caustic Leaching," PCS-TP-511-1, rev. 3, 1996, Pacific Northwest national laboratories, Richland, Washington.

3. Schreiber, R. D., "Tank 241-C-106 Grab Sampling and Analysis Plan," WHCSD-WM-TSAP-080, rev. 0, 1996, Westinghouse Hanford Company, Richland, Washington.

4. Fowler, K. D. "Data Quality Objectives for Tank Farms Waste Compatibility Program," WHC-SD-WM-DQO-001, rev. 1, 1995, Westinghouse Hanford Company, Richland, Washington.

5. Internal Memo, D. L. Herting to J. M. Jones, "Informal Test Plan for Sludge Samples from tanks 101-AY and 102-AY," dated September 20, 1995

6. Sederburg, J. P. "Chemiscal Compatibility of Tank Wastes in 241-C-106, 241-AY-101, and 241-AY-102," WHC-DS-WM-ES-290, rev. 2, 1994, Westinghouse Hanford Company, Richland, Washington.

7. Castaing, B. A. "101-AY, 102-AY and 106-C Data Compendium," WHC-SD-WM-TI-578, rev. 0, 1993 Westinghouse Hanford Company, Richland, Washington.

8. Weiss, R. L. and Schull, K. E. "Data Transmittal Package for 241-C-106 Waste Tank Characterization," SD-RE-TI-205, rev. 0, 1988, Westinghouse Hanford Company, Richland, Washington. 
[5] From: Debra L Scott at WHC167 2/23/96 2:15PM (3642 bytes: 1 In)

To: C L (Chris) McNeill at WHC396

Subject: Tests on SAMPLES FROM 241-AY-102

From: Beverly A Crawford 2/23/96 2:11PM (3377 bytes: 1 in)

To: Debra I Scott

Subject: Tests on SAMPLES FROM 241-AY-102

(1) Message Contents

Text item 1: Tests Needed

Folks :

I would like to schedule having the laboratory run the following two retrieval process support/wastyer compatability tests on C-106 sludge [using Jim Jewett's chemists, having Dan Herting do this would be advantageous since he is familiar with process support].

1. Make a dilution to 5-10\% wt. solids (Harris' choice) with the tempered "water" we will be adding to tank 102-AY (e.g., corrosion protecting mixture of $0.01 \mathrm{M}$ NAOH and $0.011 \mathrm{M}$ Sodium Nitrite).

2. Run these samt test on C-106 sluidge with the 2:1 mixture expected by diluting the AY-102 supernate which I hope we've archived with "buffered corrosion protective water.

Measure --- settling times after mild 5 minute stirring (Use Greg Lummetta's (PNNL) procedure developed for sludge washing tests.) make observations about any changes in appartent viscosity - sludge thickening etc. - - also measure visocosity, sear strenth and yield if there is a large visual change in appearance of the mixture and record anything else of retrieval (sluicing) processing interest.

Harry/Bob,

Based on what Harry's been telling us about the possible need to mix wastes together from $\mathrm{C}-106$ and $\mathrm{AY}-102$ to answer the Chemical Reaction Sub-TAP's concerns on waste compatibility, I've been doing some checking.

In answer to your questions on the condition of the AY-102 supernate immediately prior to sluicing:

The decant of $A Y-102$, and subsequent addition of raw water (chemically adjusted for corrosion control by addition of $\mathrm{NaOH}$ to $0.01 \mathrm{M}$ and NaNO2 (Nitrite) to $0.011 \mathrm{M}$ ) will serve to dilute the current supernate by a factor of about 2:1 (unless we are able to lower the level during the decant to below the OSD limit of $64 "$ "). The level in the tank after refilling is to be approximately 800,000 gallons.

It occurred to me during some discussions on this that there might be a way to avoid another sampling evolution, though. Tank AY-102 has recently had a caustic addition to return it to corrosion specifications. Therefore, there may be some archived supernate sample remaining at the labs. If so, we can use that, combined with the C-106 solids/liquids grab sample material, to perform a rudimentary mixing study in accordance with the abbreviated TSAP that 
Harry is writing up this weekend. Could I please have John Kristofzski check on this, and let Harry, Bob, or me know if that's possible? If not, we'll need George stanton to get us on a schedule for a quick grab sample of supernate from AY-102.

Either way, I'll need Bob Cash to help coordinate this effort. I'll be in touch with Bob on Tuesday (after the holiday weekend) to see what needs to happen.

Thanks,

John Harris

W-320, C-106 Sluicing Project 